\title{
DETERMINANTS OF LATENT PROFILES IN HIGHER-ORDER THINKING SKILLS OF KOREAN UNIVERSITY STUDENTS
}

\author{
Soo Eun Chae, Mi-Suk Lee \\ Gangneung-Wonju National University, South Korea \\ E-mail: schae@gwnu.ac.kr, ssuk0508@gwnu.ac.kr
}

\begin{abstract}
Past research on higher-order thinking (HOT) was mainly conducted on the bases of educational context in U.S. or western countries. This research aimed to see what kinds of HOT styles actually appear in universtiy students in South Korea. The use of HOT skills were explored in Korean universtiy students and the factors influencing the classification were examined. 1,138 Korean university students were called to respond to Lee's (2016) Higher-Order-Thinking-Scale for Korean University Students (HOTUS). Then, a latent profile analysis and the multinomial logistic analysis were conducted. The latent profile analysis revealed that the use of HOT skills could be classified into four classes (i.e., a lower-order thinking class, a creative-argumentative class, an analytical-caring class, and a higher-order thinking class). Gender, year, and instructional approach were the determinants of latent profile types. However, there were no differences when measured by academic fields. Students with lower years were likely to fall under lower-order thinking class. The probability that men was classified as a caring class was statistically significantly lower than that of women. Students who received lecturer-centered learning were more likely to fall under the analytical and caring class.
\end{abstract}

Keywords: higher-order thinking skill, latent profile analysis, multinomial logistic analysis.

\section{Introduction}

Today, it is not difficult to find a college or university without courses on creativity, fusion, and personality. Many higher educational institutions cite HOT skills as the core capabilities students need to develop during their university life and make constant efforts to foster those skills (Klein, Benjamin, Shavelson, \& Bolus, 2007). Higher-order thinking (HOT) skills, such as creativity, have become an important quality required of learners in 21 st century educational environment (Retnawati, Djidu, Kartianom, Apino, \& Anazifa, 2018), and accordingly, interest in HOT as the core skills of students is increasingly growing (Murphy, Bianchi, McCullagh, \& Kerr, 2013).

HOT skills discussed in the context of educational psychology goes quite far back. Many scholars have encouraged the development of HOT skills as an outcome of learning and teaching (Vygotsky, 1978), and emphasized education that requires higher levels of learning through analysis, synthesis and evaluation, rather than simple acquisition of knowledge (Bloom, 1956).

HOT skills mean cognitive processes at high levels, and at the same time they include emotional characteristics involving in-depth contemplation of problem situations, provision of appropriate grounds for problem solving and generation of new approaches from multiple perspectives while considering others (Lee, 2016). These HOT skills are consistent with the creativity, communication, collaboration, and critical thinking which are advocated as the key skills for the 21 st century (Soulé \& Warrick, 2015). HOT skills involve critical thinking, creative thinking, and caring thinking (Lipman, 1995) and active participation is essential in such learning scenes (Woolever \& Scott, 1988). Use of HOT skills, in most cases, accompanies kinds of activities requiring a stance of argumentation (Alexander, et al., 2011). 
Soo Eun CHAE, Mi-Suk LEE. Determinants of latent profiles in higher-order thinking skills of Korean university students

$\begin{array}{r}\text { PROBLEMS } \\ \text { OF EDUCATION } \\ \text { IN THE 21 } 1^{\text {st }} \text { CENTURY } \\ \text { Vol. } 76, \text { No. 4, } 2018 \\ \hline 484\end{array}$

\section{Problems of Research}

Recently, many universities in Korean society emphasize HOT as core skills in preparation for environmental changes in $21^{\text {st }}$ century. Regardless of the long history of the HOT academy in western culture, little studies were conducted to investigate what kinds of HOT styles actually appear in university students in countries other than U.S. This research was conducted in hope of finding the profiles existing behind the HOT skills of Korean university students and to understand how the profiles obtained from the analysis differ according to different years, genders and academic fields. Based upon the research problems, we addressed the following two research questions:

What do the HOT skill profiles of Korean university students look like?

How do the HOT skill profiles of Korean university students differ according to different years, genders, academic fields and instructional approaches?

\section{Research Focus}

\section{Higher-Order Thinking Skills}

In its long history, the concept of thinking or thought has changed in diverse ways. Thinking can be simply "everything that comes to mind or goes through the head" but it is also "seeking the ground or basis for one's belief and its adequacy to support the belief" (Dewey, 1999). Dewey called the latter concept a "reflected thought," which alone, he believed, was truly educative in value. Drawing upon this concept, philosophers drew the concept of critical thinking and reflective thinking and psychologists defined the concept of problem solving skills (Lewis \& Smith, 1993). In the late 1980s, these concepts together began to be emphasized in social studies under the name "higher-order thinking skills" (Jeon, 2010) in Korea. These higher-order thinking skills refer to "a cognitive ability to solve a problem critically, creatively and caringly when individuals encounter a problematic situation, instead of dealing with it with familiar knowledge or experience" (Lipman, 1995; Newmann, 1987). Given the existent literature, we saw Higher-order thinking skills as comprising components of creative thinking skills, critical thinking skills and caring thinking skills.

Creative thinking skills refer to the ability in the cognitive domain of creativity (O'Sullivan \& Guilford, 1975) which allows people to think up new and useful ideas when they face problem situations (Amabile et al., 2005; O'sullivan \& Guilford, 1975). Creativethinking has the dimensions of fluency, flexibility, originality and elaboration. Fluency is the ability to generate a large number of ideas and flexibility is the ability to shift approaches and find solutions from new and unconventional perspectives. Originality is the ability to generate original and unusual ideas and elaboration is the amount of detail or completeness manifested to existing ideas (Torrance, 1988)

Critical thinking refers to the cognitive domain of critical thinking (Facione, 1990) which is the ability to make accurate and sound judgments based on the given criteria when people are faced with certain problems (Bandman, 1988; Kemp, 1963; Norris, 1985). It is analytical, argumentative and dialectical. Analytical thinking means "dividing one whole into many parts, examining in detail, thoroughly investigating issues or situations" and argumentative thinking involves "drawing conclusions from given data or providing appropriate grounds to justify certain argument." Dialectical thinking is "the ability to connect many parts into one whole or the ability to approach given situations with different ideas or the ability to generate better alternatives from broader perspectives" (M. Kim, 2007, pp. 25-34).

Caring thinking refers to the cognitive domain of caring (Soo-dong Kim, Ahn, \& Lee, 2014) which involves a cognitive ability (Jin-sook, 2011; Park, 2011)to allow people to make sound judgments when they encounter certain problems based on interest and empathy of others. Lipman sees caring thinking as having five features: appreciative thinking, affective thinking, 
active thinking, normative thinking and empathetic thinking, and these features have 39 subfeatures. Appreciative thinking is "to pay attention to what matters, to what is of importance,"

PROBLEMS OF EDUCATION IN THE $21^{\text {st }}$ CENTURY Vol. 76, No. 4, 2018 and affective thinking is "dealing with others with love, joy, friendship, sadness, anger and other emotional attachments." Active thinking is "to lead selfless actions to actively take care of others," normative thinking is "to think, reflect and explore one's own values required in society," and empathetic thinking is "to feel the emotions and experiences of others in others' positions" (Lipman, 2003, pp. 264-270).

\section{Measurement of Higher-Order Thinking Skills}

The scale employed in this research is HOTUS (Higher-Order Thinking Skill Scale for University Students) developed by Lee (2016). Developed to meet the special conditions of Korean university students' academic scenes, the scale has the following characteristics:

HOT is classified between a cognitive domain and an affective domain and an inventory has been developed by characterizing the cognitive domain. HOT has been studied without a clear distinction between cognitive domain and affective domain, but a closer look into these previous studies reveals that they mostly focused on the cognitive domain. As shown in Figure 1 , this research has a clear distinction between the domains and the elements under HOT are also composed as the elements of the cognitive domain.

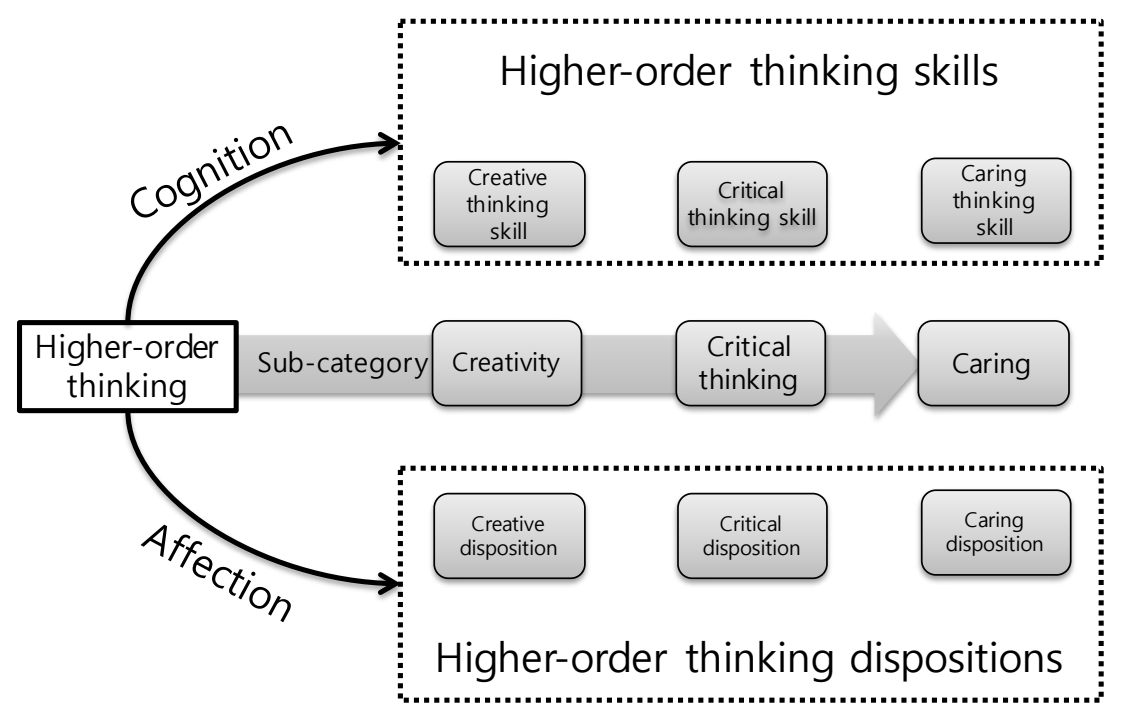

Figure 1. Structure of higher-order thinking.

This scale reflects all HOT skills derived from the early development of precedent study and consists of a total of 133 question items across 8 categories of factors: 14 items in fluency, 11 items in flexibility, 14 items in originality, 15 items in elaboration, 15 items in analysis, 15 items in argumentation, 23 items in dialectical and 26 items in caring. The scale was then reviewed through an expert meeting, university student pilot study and validity and reliability check and eventually narrowed down to form 25 items in 5 factors. The final selection of factors and relevant items is as shown in Table 1. 
PROBLEMS

OF EDUCATION

IN THE $21^{\text {st }}$ CENTURY Vol. 76, No. 4, 2018

486

Table 1. Attribute definitions and the number of items by sub-factor of higherorder thinking skills for Korean university students.

\begin{tabular}{ll}
\hline $\begin{array}{l}\text { Sub-Factor } \\
\text { (number of items) }\end{array}$ & Definition \\
\hline Analysis (4) & $\begin{array}{l}\text { Cognitive ability to contemplate a problem situation in detail } \\
\text { Cognitive ability to generate new and useful ideas when facing problem situations } \\
\text { Creativity (4) }\end{array}$ \\
Argumentation (5) & $\begin{array}{l}\text { Cognitive ability to provide adequate grounds for justifying conclusions about problem } \\
\text { situations } \\
\text { Cognitive ability to provide, synthesize and devise new forms of alternatives from } \\
\text { various perspectives about problem situations }\end{array}$ \\
Caring (7) & $\begin{array}{l}\text { Cognitive ability to seek reasonable approaches or thoughts about problem situations } \\
\text { based on interest and empathy of others }\end{array}$ \\
\hline
\end{tabular}

Note. The table is adopted from Lee (2016).

Determinants of Use of Higher-Order Thinking

According to the meta-analysis published by Budsankom et al. (2015), learning environment and psychological cognitive characteristics of students strongly and directly predicted HOT skills (96.8\% variance explained). Family variable was also a determinant of HOT skills but its indirect effect was bigger. In that study, Budsankom et al. collected HOT skill-related studies carried out in Thailand from 1999 to 2013 and analyzed the mathematical structural equation modeling (MASEM). The analysis of 166 studies revealed that the family variable did not have a significant impact overall, but the learning environment or personal variables had a substantial impact. In particular, while the psychological characteristics of each student were also a direct determinant of HOT skills, they played a role as a medium for the school environment and family variables to influence HOT skills. In addition, the school variable was found to have a rather indirect impact, because the school variable, including the way a class is run or managed, contributed to facilitating HOT skills by fostering the attitudes, feelings, knowledge and other psychological aspects of students (Schumacker \& Lomax, 2010).

In fact, many studies in the past reported that instructional approaches and free academic activities in universities contributed to enhancing critical thinking, creative thinking and other high-order thinking skills. For example, the learning models that focus on learners, such as problem-based learning, are known to be a classic learning method to enhance HOT skills in students (Raiyn \& Tilchin, 2015). Learning mathematics through contextual class, rather than through symbol or text-based learning environment is also known to have contributed to improving HOT skills (Samo, Darhim, \& Kartasasmita, 2017). According to the recent metaanalysis, interactive class, practical and contextual problem-based class and teachers' mentoring were the factors that affected the critical thinking ability (Abrami et al., 2014). Student-centered learning and teaching method such as problem based learning (Mokhtar, Tarmizi, Tarmizi, \& Ayub, 2010) and project based learning (Vidergor \& Krupnik-Gottlieb, 2015) have been called to develop HOTS.

\section{Methodology of Research}

\section{General Background of Research}

Given the precedent research, this research focused on exploring the types of HOT utilization and the factors that determine such utilization of HOT. As candidate variables that influence the formation of HOT, school and student variables, examined by Budsankom et al. were included. The school variables included in this research are the ways a classroom is run 
(Lecturer-centered, Lecturer and student-centered, student-centered) and the student variables included gender, academic fields and years. Especially, the general expectation that students'

PROBLEMS OF EDUCATION IN THE $21^{\text {st }}$ CENTURY Vol. 76, No. 4, 2018

487 ability to utilize HOT would increase during university life was employed. In addition, it was expected that there would be differences in the way HOT is utilized among students, based on the thinking pattern theory according to gender and academic fields (e.g., Onyeruru, 2015; Seo, 2003).

\section{Sample of Research}

A survey was conducted in November 2015 for university students from 6 regions (Seoul, Gyeonggi-do, Gangwon-do, Chungcheong-do, Jeolla-do, and Gyeongsang-do). A total of 1,713 copies of the questionnaire were distributed, of which 1,226 copies were collected. Of these, 88 copies with unreliable responses or missing values were removed, and 1,138 copies were eventually analyzed. All the subjects agreed to participate in the research by signing a written consent form. A higher percentage of lower year students participated in the survey. Specifically, 501 students $(44.02 \%)$ were male and 506 students $(44.46 \%)$ were in year 1,265 students (23.29\%) in year 2 and 230 students $(20.21 \%)$ in year 3 . Table 2 shows the demographic characteristics of the research participants.

Table 2. Demographic characteristics of study participants.

\begin{tabular}{|c|c|c|c|}
\hline Variable & & $\mathbf{N}$ & $\%$ \\
\hline \multirow{2}{*}{ Gender } & Male & 501 & 44.02 \\
\hline & Female & 637 & 55.98 \\
\hline \multirow{4}{*}{ Year } & Year 1 & 506 & 44.46 \\
\hline & Year 2 & 265 & 23.29 \\
\hline & Year 3 & 230 & 20.21 \\
\hline & Year 4 & 137 & 12.04 \\
\hline \multirow{5}{*}{ Academic Field } & Humanities and Social Sciences & 640 & 56.24 \\
\hline & Science and Engineering & 260 & 22.85 \\
\hline & Arts and Physical Education & 162 & 14.24 \\
\hline & Medical & 58 & 5.10 \\
\hline & Others & 18 & 1.58 \\
\hline \multirow{6}{*}{ Location } & Seoul & 259 & 22.76 \\
\hline & Gyeonggi-do & 342 & 30.05 \\
\hline & Gangwon-do & 110 & 9.67 \\
\hline & Chungcheong-do & 176 & 15.47 \\
\hline & Jeolla-do & 152 & 13.36 \\
\hline & Gyeongsang-do & 99 & 8.70 \\
\hline \multirow{4}{*}{$\begin{array}{l}\text { Instructional } \\
\text { Approach }\end{array}$} & Lecturer-centered & 885 & 77.8 \\
\hline & Lecturer + students & 167 & 14.7 \\
\hline & Student-centered & 86 & 7.6 \\
\hline & Total & 1138 & 100.0 \\
\hline
\end{tabular}


Soo Eun CHAE, Mi-Suk LEE. Determinants of latent profiles in higher-order thinking skills of Korean university students

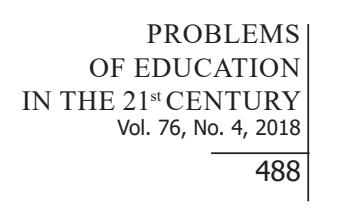

PROBLEMS

DUCATION

$21^{\text {st }}$ CENTURY

488

88

HOTUS (Higher-Order Thinking Skill Scale for University Students) consists of the subcategories of creative thinking, critical thinking and caring thinking, and each sub-category includes question items regarding creativity, analysis, argumentation, dialectic and caring that explain HOT skills (Lee, 2016). Creativity is the cognitive ability to generate new and useful ideas; analysis is the cognitive ability to examine problem situations in detail; argumentation is the cognitive ability to give an appropriate basis for the expected conclusion; dialectic is the cognitive ability to put forward and synthesize various perspectives and create new alternatives; and caring is the cognitive ability to seek a reasonable method or idea based on interest and empathy of others. HOTUS contains a total of 25 questions (4 questions for creativity, 4 questions for analysis, 5 questions for argumentation, 5 questions for dialectic and 7 questions for caring) and averages of scores on a 5-point Likert scale ( $1=$ very unlikely, $5=$ very likely) are calculated. The internal consistency reliability of HOTUS was reported as 879 (Lee, 2016). The definitions and the number of questions of each subconstruct in this scale are as shown in Table 1. The detailed list of questions is provided in the Appendix.

Variables (gender, year, academic field, location and instructional approach) to be treated as independent variables were also surveyed. Students were asked to choose one academic field from (1) humanities and social sciences (2) science and engineering, (3) arts and physical education (4) medical and (5) others. As to instructional approach provided to students, students chose one of the following five options: (1) more than $90 \%$ of Lecturer-centered (2) $70 \%$ of Lecturer-centered $+30 \%$ of student participation (3) $50 \%$ of Lecturer-centered $+50 \%$ of student participation, (4) 30\% of Lecturer-centered $+70 \%$ of student participation, and (5) more than $90 \%$ of student participation. For the convenience of analysis, (1) and (2) replies were grouped as Lecturer-centered, (3) replies were treated as Lecturer + student style, and (4) and (5) replies were grouped as student-centered.

\section{Data Analysis}

In this research, latent profiles of HOT skill types were classified and the profiles were then analyzed using $M$ plus 7.11 to validate the influence of the relevant variables. In class classification, the sub-classes estimated from the analysis of replies are called latent profiles. The latent profile analysis is called a person-oriented approach that distinguishes classes through personal characteristics and attributes (Bergman \& Magnusson, 1997). The latent profile analysis relies on data to produce the number of classes, and does not require statistical assumptions (linearity, normality of data, homogeneity of variance) required in cluster group analysis (Sa-hyeon Kim \& Hong, 2010). The ability to overcome the limitation that three or more nominal scales cannot be analyzed is another merit of this analysis (Yang, Kim, \& Hwang, 2007).

First, entropy was checked to identify the quality of the classification. Entropy is between 0 and 1 , and its value increases when the probability of belonging to one latent class is closer to 1 and the probability of belonging to another latent class is closer to zero. Entropy with approximately 0.8 or more can be seen as a good classification (Clark, 2010). Next, the fit of the model-data, such as AIC (Akaike Information Criterion), BIC (Bayesian Information Criterion), and SABIC (Sample-size Adjusted BIC) was verified. Finally, comparison and validation for the model was conducted using the Mendell-Rubin adjusted likelihood ratio test (LMRLRT) and the parametric bootstrapped likelihood ratio test (BLRT).

Multinomial logistic analysis was employed to identify candidate variables (gender, academic field and instructional approach) that influenced the formation of the latent profiles. In performing this analysis, the latent profiles were input as dependent variables and other influencing factors were input as independent variables. As the multinomial logistic analysis should be interpreted on the basis of the reference group, the last group set as the default value in SPSS was used. 
Figure 2 shows the research model of this research. The model was intended to find latent profiles from the 25 questions of HOT skills and to explore the degree of impact of the variables - i.e., gender, academic field, location and instructional approach - on the formation of the latent profiles.

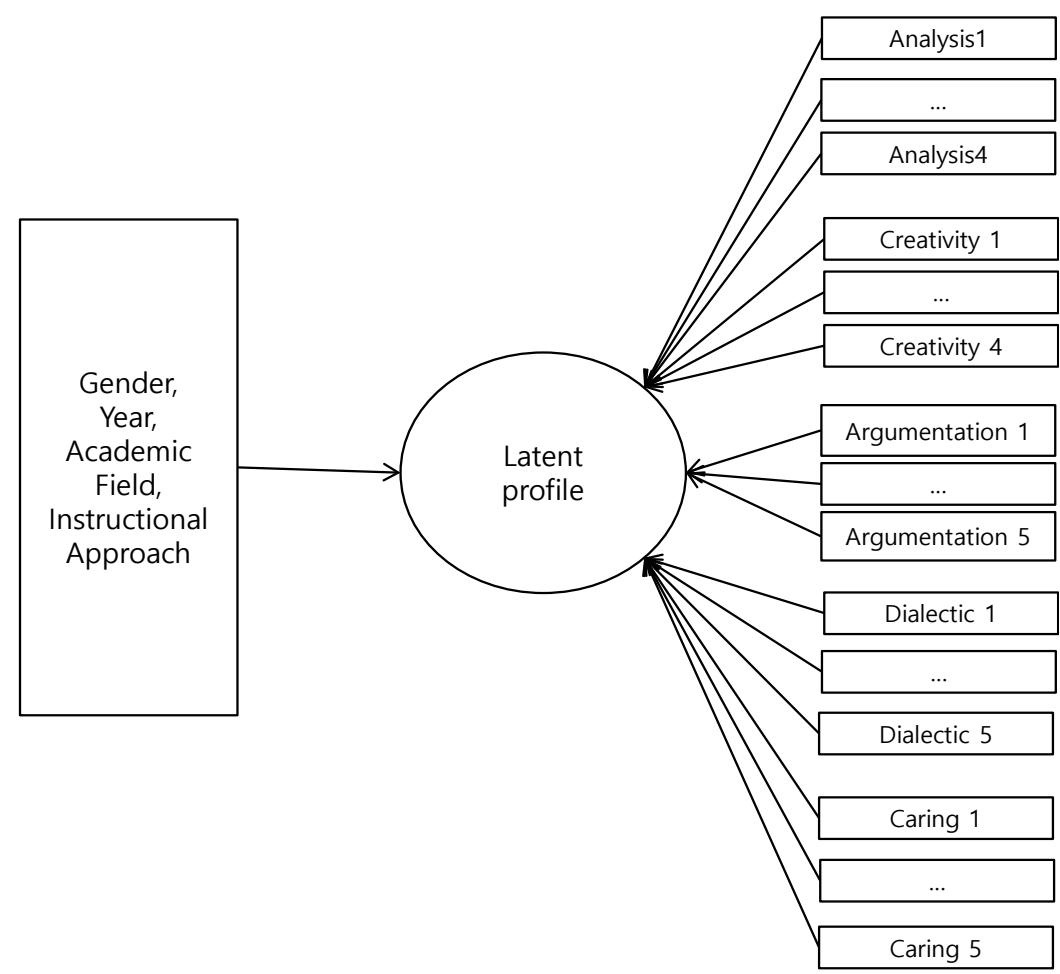

Figure 2. The Research Model of HOT LCA.

\section{Results of Research}

\section{Latent Class Analysis}

Table 3 summarizes the descriptive statistics of the sub-variables of HOT skills employed in the latent class analysis. As seen in the Table, the five sub-variables of HOT skills showed a statistically significant correlation of an approximately medium level, but in some matching pairs such as between analysis and creativity and between caring and creativity, the correlation was very low or hardly existent. 
PROBLEMS

OF EDUCATION

IN THE $21^{\text {st }}$ CENTURY Vol. 76, No. 4, 2018

490

Table 3. Descriptive statistics and correlations among sub-variables of higherorder thinking skills.

\begin{tabular}{llllll}
\hline$\square$ & 1 & 2 & 3 & 4 & 5 \\
\hline 1.Analysis & 1 & & & & \\
\hline 2.Creativity & $.171^{* *}$ & 1 & & & \\
\hline 3.Argumentation & $.501^{* *}$ & $.268^{* *}$ & 1 & & \\
\hline 4.Dialect & $.408^{* *}$ & $.449^{* *}$ & $.428^{* *}$ & 1 & 1 \\
\hline 5.Caring & $.385^{* *}$ & $.070^{*}$ & $.396^{* *}$ & $.378^{* *}$ & 3.74 \\
\hline Mean & 3.72 & 2.92 & 3.50 & 3.36 & 0.54 \\
\hline S.D. & 0.61 & 0.68 & 0.56 & 0.59 & \\
\hline Notes. $* \mathrm{p}<05, * * \mathrm{p}<01$ & & & & &
\end{tabular}

Notes. ${ }^{*} \mathrm{p}<.05,{ }^{* *} \mathrm{p}<.01$

Table 4 shows the results of the latent profile analysis for HOT skills of university students. In the latent profile analysis, the number of classes exposed from the data is determined considering the ease of interpretation and the fit of the model. The fit of the model was checked by increasing the number of profiles from two to five.

Table 4. Model fit by the number of latent profile classes.

\begin{tabular}{lllllll}
\hline & AIC & BIC & SABIC & Entropy & LMRLRT & BLRT \\
\hline 2 Profiles & 64380.764 & 64763.578 & 64522.179 & 0.876 & 0.00 & 0.00 \\
\hline 3 Profiles & 63314.271 & 63828.047 & 63504.065 & 0.844 & 0.00 & 0.00 \\
\hline 4 Profiles & 62586.207 & 63230.946 & 62824.38 & 0.841 & 0.01 & 0.00 \\
\hline 5 Profiles & 62119.997 & 62895.699 & 62406.55 & 0.862 & 0.22 & 0.00 \\
\hline
\end{tabular}

It is known that the comparison results of model fits are well differentiated when the entropy index is 0.8 or higher (Muthen \& Muthen, 2007). The classification was almost accurate with the entropy values of the models compared in this research all showing 0.8 or more. Values of AIC, BIC, and SABIC all decreased as the number of latent profiles increased. LMRLRT was significant for up to four models, and BLRT was significant for all models, so it is difficult to determine which model is fit with these criteria. A researcher's judgment becomes important when multiple indices show different results (Kim Sa-hyeon et al., 2010), and in such cases, it is necessary to comprehensively consider various fit indices and theoretical interpretability (Cho Jee-yong et al., 2013). A four-class classification was employed in this research, comprehensively taking into account the ease of interpretation, fit index and other aspects. 


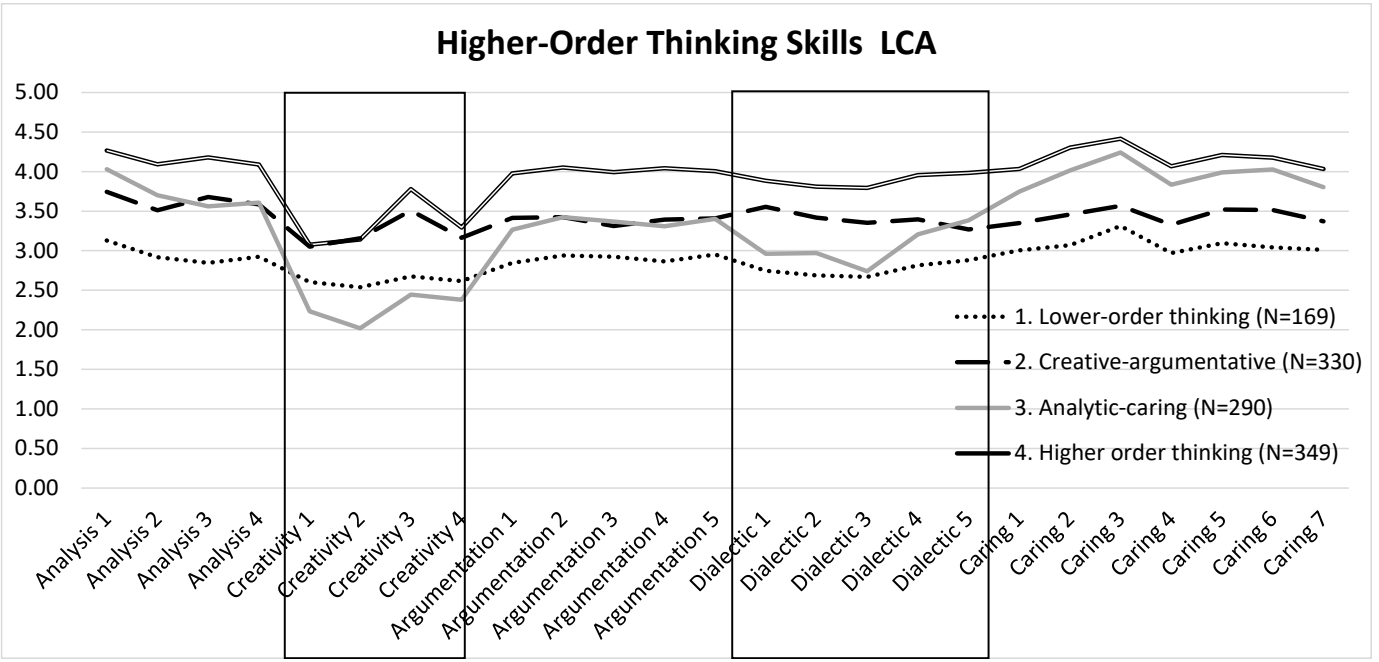

Figure 3. Means of item scores per LCA class of higher-order thinking skills.

Figure 3 outlines the latent profiles produced. The characteristics of each type of profile are as follows: First, Class 1 showed low scores in most indicators including analysis, argumentation, dialectic and caring compared with other groups. This class can be termed "a lower-order thinking class." 169 students belonged to this class, accounting for $15 \%$ of all students. Class 2 earned relatively high scores, ranking second in creativity, argumentation and dialectic among all classes, but its caring score was relatively low. This class can be named "a creative and argumentative class." 330 students, or 29\% were in this class. Class 3 had high scores in analysis, argumentation and caring and relatively low scores in creativity and dialectic. Given the high construct correlation between creativity and argumentation among the lower HOTUS scores, this group can be understood as having weak creative and divergent thinking but having exceptionally strong analytical and caring mind. Therefore, it can be called "an analytical and caring class." This class had 290 students, which comprised $25 \%$ of the total number of students. The last class is the so-called "higher-order thinking class" whose scores were high across all subconstructs. 349 students belonged to this class, accounting for $31 \%$ of the total number of students.

\section{Factors That Influence the Latent Profiles of Higher-Order Thinking Skills}

Table 5 shows the basic descriptive statistics of the four classes according to the variables of interest of this research. Cross-tabulation analysis produced a statistically significant difference overall, but no significant difference was produced only in academic fields.

In gender indicator, the ratio of female students in the analytical and caring class was much higher than that of male students. According to Chi-square analysis, such difference was statistically significant $\left(\chi^{2}=24.851, \mathrm{p}=.001\right) .198$ students belonged to the analytical and caring class, accounting for $31 \%$ of 637 participating female students. On the other hand, the number of male students in the same class was 92 , or only $18 \%$ of 501 students.

HOT types were significantly different by year $\left(\chi^{2}=23.594, \mathrm{p}=.005\right)$. Overall, the percentage of HOT students increased in year 4 . Among the first-year students, 145 students belonged to the HOT class, accounting for only $29 \%$, but in year 4, 50 out of 137 fourth year students, or $36 \%$ belonged to the HOT class. The proportion of students in the analytical and caring class also increased as the year level increased. Conversely, the percentage of students belonging to the lower-order thinking class decreased as the year level increased ( $20 \%$ in year 1 vs. $40 \%$ in year 4). The creative and argumentative class showed a high ratio in year 2 at $34 \%$, but the ratio declined in year 4 . 
PROBLEMS

OF EDUCATION

IN THE $21^{\text {st }}$ CENTURY Vol. 76, No. 4, 2018

492

In academic fields, the most prominent among science and engineering students were the HOT class and the creative and argumentative class which accounted for $31 \%$ of student subjects, respectively. Students in arts and physical education were most populated in the creative and argumentative class (31\%), while many of the medical students belonged to the high-order thinking class (41\%). Among the students in humanities and social sciences, the biggest number of students was in the HOT class $(30 \%)$, followed by the analytical and caring class $(29 \%)$. However, the difference was marginal, indicating that there was no statistically significant correlation between academic fields and HOT skill patterns ( $\chi^{2}=18.440, \mathrm{p}=.103$ ).

Table 5. Four-Class composition based on variables of interest $(\mathbf{N}, \%)$.

\begin{tabular}{|c|c|c|c|c|c|c|c|c|c|c|}
\hline \multirow{2}{*}{\multicolumn{2}{|c|}{$\begin{array}{l}\text { Variable } \\
\text { Total }(\mathrm{N}=1138)\end{array}$}} & \multicolumn{2}{|c|}{$\begin{array}{l}\text { Lower-Order } \\
\text { Thinking } \\
\text { Class }\end{array}$} & \multicolumn{2}{|c|}{$\begin{array}{l}\text { Creative -Ar- } \\
\text { gumentative } \\
\text { Class }\end{array}$} & \multicolumn{2}{|c|}{$\begin{array}{l}\text { Analytical - } \\
\text { Caring Class }\end{array}$} & \multicolumn{2}{|c|}{$\begin{array}{l}\text { Higher-Order } \\
\text { Thinking Class }\end{array}$} & \multirow[t]{2}{*}{$\begin{array}{l}\text { Pearson } \\
\text { (p-value) }\end{array}$} \\
\hline & & 169 & $15 \%$ & 330 & $29 \%$ & 290 & $25 \%$ & 349 & $31 \%$ & \\
\hline \multirow{2}{*}{ Gender } & Male $(\mathrm{N}=501)$ & 87 & 17 & 155 & 31 & 92 & 18 & 167 & 33 & \multirow{2}{*}{$\begin{array}{l}24.851 \\
(.001)\end{array}$} \\
\hline & Female $(\mathrm{N}=637)$ & 82 & 13 & 175 & 27 & 198 & 31 & 182 & 29 & \\
\hline \multirow{4}{*}{ Year } & Year $1(\mathrm{~N}=506)$ & 101 & 20 & 133 & 26 & 127 & 25 & 145 & 29 & \multirow{4}{*}{$\begin{array}{l}23.594 \\
(.005)\end{array}$} \\
\hline & Year $2(\mathrm{~N}=265)$ & 27 & 10 & 90 & 34 & 63 & 24 & 85 & 32 & \\
\hline & Year $3(\mathrm{~N}=230)$ & 27 & 12 & 71 & 31 & 63 & 27 & 69 & 30 & \\
\hline & Year $4(\mathrm{~N}=137)$ & 14 & 10 & 36 & 26 & 37 & 27 & 50 & 36 & \\
\hline \multirow{5}{*}{$\begin{array}{l}\text { Aca- } \\
\text { demic } \\
\text { Field }\end{array}$} & $\begin{array}{l}\text { Humanities and } \\
\text { Social Sciences } \\
(\mathrm{N}=640)\end{array}$ & 82 & 13 & 177 & 28 & 183 & 29 & 193 & 30 & \multirow{5}{*}{$\begin{array}{l}18.440 \\
(.103)\end{array}$} \\
\hline & $\begin{array}{l}\text { Science and Engi- } \\
\text { neering }(\mathrm{N}=260)\end{array}$ & 44 & 17 & 80 & 31 & 55 & 21 & 81 & 31 & \\
\hline & $\begin{array}{l}\text { Arts and Physical } \\
\text { Education }(N=162)\end{array}$ & 34 & 20 & 52 & 31 & 37 & 22 & 44 & 26 & \\
\hline & Medical $(\mathrm{N}=58)$ & 6 & 10 & 15 & 26 & 13 & 22 & 24 & 41 & \\
\hline & Others $(\mathrm{N}=18)$ & 3 & 17 & 6 & 33 & 2 & 11 & 7 & 39 & \\
\hline \multirow{3}{*}{$\begin{array}{l}\text { Instruc- } \\
\text { tional } \\
\text { Ap- } \\
\text { proach }\end{array}$} & $\begin{array}{l}\text { Lecturer-centered } \\
(\mathrm{N}=885)\end{array}$ & 132 & 15 & 250 & 28 & 241 & 27 & 262 & 30 & \multirow{3}{*}{$\begin{array}{l}14.223 \\
(.027)\end{array}$} \\
\hline & $\begin{array}{l}\text { Lecturer + stu- } \\
\text { dents }(\mathrm{N}=167)\end{array}$ & 26 & 16 & 50 & 30 & 40 & 24 & 51 & 31 & \\
\hline & $\begin{array}{l}\text { Student-centered } \\
(\mathrm{N}=86)\end{array}$ & 11 & 13 & 30 & 35 & 9 & 10 & 36 & 42 & \\
\hline
\end{tabular}

The differences by instructional approach were also significant ( $\chi^{2}=14.223, \mathrm{p}=.027$ ). Among the students who received Lecturer-centered learning, the percentage of HOT class was slightly higher $(30 \%)$ than the other classes (lower-order thinking, creative and argumentative, analytical and caring). This figure is small compared with $42 \%$ of HOT class students among the students who received student-centered learning.

To identify the factors that influence latent profiles, a multinomial logistic analysis was conducted using the higher-order thinking class (Class 4) as a reference group. Among the candidate influence factors, gender, year, and instructional approach were found to be statistically significant, which is consistent with the statistics in Table 5 (the last line of Table 6). 
Table 6. Multinomial logistic analysis results of higher-order thinking skill types.

\begin{tabular}{|c|c|c|c|c|}
\hline & & Odds Ratio & Standard Error & $p$ \\
\hline \multirow{10}{*}{$\begin{array}{l}\text { 1. Lower-Order } \\
\text { Thinking Class }\end{array}$} & Male & 1.056 & .200 & .786 \\
\hline & Year 1 & 2.631 & .336 & $.004^{*}$ \\
\hline & Year 2 & 1.276 & .386 & .527 \\
\hline & Year 3 & 1.468 & .381 & .314 \\
\hline & Humanities and Social Sciences & .936 & .725 & .928 \\
\hline & Science and Engineering & 1.261 & .744 & .755 \\
\hline & Arts and Physical Education & 1.664 & .745 & .494 \\
\hline & Medical & .597 & .841 & .540 \\
\hline & Lecturer -Centered & 1.702 & .376 & .158 \\
\hline & Lecturer + student & 1.736 & .437 & .207 \\
\hline \multirow{10}{*}{$\begin{array}{l}2 . \\
\text { Creative and } \\
\text { Argumentative } \\
\text { Class }\end{array}$} & Male & .943 & .163 & .720 \\
\hline & Year 1 & 1.298 & .254 & .305 \\
\hline & Year 2 & 1.528 & .275 & .123 \\
\hline & Year 3 & 1.447 & .279 & .185 \\
\hline & Humanities and Social Sciences & 1.016 & .580 & .978 \\
\hline & Science and Engineering & 1.188 & .598 & .774 \\
\hline & Arts and Physical Education & 1.363 & .603 & .608 \\
\hline & Medical & .722 & .653 & .618 \\
\hline & Lecturer-Centered & 1.138 & .271 & .633 \\
\hline & Lecturer + student & 1.170 & .326 & .630 \\
\hline \multirow{10}{*}{$\begin{array}{l}\text { 3. Analytical and } \\
\text { Caring Class }\end{array}$} & Male & .488 & .175 & $<.0001$ \\
\hline & Year 1 & 1.072 & .257 & .787 \\
\hline & Year 2 & .805 & .287 & .451 \\
\hline & Year 3 & 1.153 & .285 & .616 \\
\hline & Humanities and Social Sciences & 2.662 & .831 & .239 \\
\hline & Science and Engineering & 2.261 & .849 & .337 \\
\hline & Arts and Physical Education & 2.512 & .854 & .281 \\
\hline & Medical & 1.428 & .893 & .690 \\
\hline & Lecturer -Centered & 3.352 & .391 & $.002^{*}$ \\
\hline & Lecturer + student & 2.777 & .437 & $.020^{*}$ \\
\hline \multirow[t]{2}{*}{ Model Fit } & -2 Log Likelihood & 651.823 & & \\
\hline & Chi Square & 79.955 & $\begin{array}{l}\text { Significance Prob- } \\
\text { ability }\end{array}$ & $p<.0001$ \\
\hline
\end{tabular}

Note. ${ }^{*} \mathrm{p}<.05$

Specifically, in the lower-order thinking class, the first year showed a significant difference compared to the fourth year $(\mathrm{p}=.004)$, which is the reference group. Among the first year students, the odds ratio classified as a lower-order thinking class was 2.631 , which is $163.1 \%$ higher than fourth year students. This tendency was also very high in the second year students $(27.6 \%)$ and in the third year students $(46.9 \%)$, but statistical significance was not found ( $\mathrm{p}=.527, \mathrm{p}=.314$, respectively). Gender, academic field and instructional approach did not have a big impact on the classification of students as a lower-order thinking class compared with the higher-order thinking class. 


\begin{abstract}
PROBLEMS
OF EDUCATION

IN THE $21^{\text {st }}$ CENTURY Vol. 76, No. 4, 2018

494 class was all less than the significance level of .5

The probability of belonging to the analytical and caring class seemed to be more obvious than the reference group (higher-order thinking class) according to gender and instructional approach. The probability that men will be classified as a caring class was statistically significantly lower than that of women. In case of men, the odds ratio of belonging to the analytical and caring class was 0.488 , which is interpreted to be significantly reduced by $51.2 \%$ $\left[(1-0.48)^{*} 100\right]$ compared to that of women $(\mathrm{p}<.001)$. Students who received Lecturer-centered learning showed that the odds ratio of belonging to the analytical and caring class increased by $235.2 \%$ compared to other students who received student-centered learning. On the other hand, the odds ratio of belonging to the analytical and caring class among the students who received Lecturer + student type of learning increased by $177.7 \%$ compared to those who received student-centered learning.
\end{abstract}

\section{Discussion}

In this research, the possibility of classifying the use of HOT skills was explored and if such classification was possible, the factors influencing the classification were examined. To do this, a survey was conducted for Korean university students using the inventory for HOT skill utilization developed by Lee (2016), and the survey data was used to perform latent profile analysis and the multinomial logistic analysis.

The latent profile analysis revealed that the use of HOT skills could be classified into a total of four classes. Various indices used for the classification clarified the distinction of the classes. Based on the characteristics of these four classes, they were named as a lower-order thinking class, a creative and argumentative class, an analytical and caring class, and a higherorder thinking class, respectively. The lower-order thinking class showed very low scores in all of the five subconstructs (analysis, creativity, argumentation, dialectic, and caring) of higherorder thinking skill utilization. On the other hand, the higher-order thinking class showed high scores in all subconstructs.

The creative and argumentative class and the analytical and caring class have very unique characteristics. The creative and argumentative class showed high scores in creativity and argumentation on average but showed average or lower than average scores in other areas. In other words, students in creative and argumentative class act creatively when they solve problems in an original way or actively participate in discussions, but they are somewhat timid about following rules or caring or empathizing with others. In the analytical and caring class, the creativity score distribution was very low, but the analysis and argumentation scores were high, and the caring was significantly higher than the average. The analytical and caring class is a group of students who seem to have HOT ability but somehow lack flexibility or creativity. This type of students is common in real-life schools.

To understand the background of students from each of the four classes identified from the latent profile analysis, gender, year, academic field, and instructional approach were examined and the differences were compared. The results were generally consistent with the findings of the precedent study. That is, gender, year, and instructional approach were the determinants of latent profile types (e.g., Schumacker \& Lomax, 2010). However, unlike the previous discussions on different learning style across domains (Seo, 2003), there were no significant differences when compared by academic fields.

Among many factors, the differences in instructional approaches and the differences in the development of HOT skills have already been strongly asserted in previous studies. In other words, the assertion of previous studies (Abrami et al., 2014) that contextual learning focusing on students such as PBL and PjBL (Mokhtar et al., 2010; Raiyn \& Tilchin, 2015) would help increase HOT skills in students was somewhat proved through this research. In 
particular, it was found that students who received Lecturer-centered learning were more likely to fall under the analytical- caring class than creative-argumentative class. Considering that the students who were classified as the analytical and caring class in this research are more likely to display lower than average scores in creativity and dialectic, this phenomenon seems plausible. In other words, it can be interpreted as meaning that the students who took learner-centered class are more likely to be creative and flexible and put forth opinions from different point of views. On the other hand, the more Lecturer's guidance is involved, students are more likely to think attentively and care for others, although they are less creative. While it is encouraging in that this type of thinking is consistent with what learner-focused classrooms intended to achieve, whether only learners' initiative should be emphasized in classrooms is questionable, considering that the analytical and caring aspects cannot be ignored in this research's base model for HOT skills (Lipman, 2003). As much as the need to be creative and self-assertive depending on situations and society, one needs to be mindful and receptive to others and in this regard, the argument that all university curriculum or instructional approaches should be centered around learners needs further discussions.

Differences in the use of HOT skills by academic field were not statistically significant and this is primarily related to the background against which this inventory was developed. One of the objectives of the inventory development intended by Lee (2016) was to make a crossdisciplinary and cross-sectional inventory that could be used irrespective of academic fields. This intention was confirmed again by the latent profile analysis, thus enhancing the validity of the development and use of the inventory.

This research also identified the differences in the use of HOT skills according to the year level, which is a natural and encouraging finding in the larger context of promoting HOT skills through university education. However, whether these differences are due to the actual changes occurring to individual students with year change or whether they are the result of learning in universities left room for further analysis through development-specific research design.

\section{Conclusions}

The current research findings indicate that different HOT styles appear in Korean University students. A considerable number of students appeared to contain high levels of HOT skills in every underlying construct (i.e., Analysis, Creativity, Argumentation, Dialect, and Caring), which was named 'higher-order thinking class'. A small portion of the students were likely to show less usage of the constructs (lower-order thinking class). In the middle, there were two classes of students with greater use of creativity and argumentation and those with greater use of analysis and caring. The different HOT styles in the students were significantly related to their gender, year levels, and instructional method they have taken.

The different revelation of the HOT styles and the significant relation to the learner variables call us to think appropriate teaching method for University students for 21st century. Many schools in the present era tend to incorporate student-centered learning approach regardless of their school philosophy merely due to the current educational trend. Different HOT styles seemed to appear along with the students' learning environments. It seems necessary to see what kinds of higher-order thinkers the school desires to produce and then to set out appropriate instructional method for the students. The current study particularly found creativeargumentative graduates are likely to come forth in greater numbers when student-centered teaching was provided, whereas analytical-caring graduates are more produced with Lecturercentered teaching. Students' talents should be considered instead of simply striving to increase all the underlying HOT constructs.

\author{
PROBLEMS \\ OF EDUCATION \\ IN THE $21^{\text {st }}$ CENTURY \\ Vol. 76, No. 4, 2018 \\ 495
}


Soo Eun CHAE, Mi-Suk LEE. Determinants of latent profiles in higher-order thinking skills of Korean university students

\section{PROBLEMS \\ OF EDUCATION \\ IN THE $22^{\text {st }}$ CENTURY Vol. 76, No. 4,2018 \\ 496 References}

Abrami, P. C., Bernard, R. M., Borokhovski, E., Waddington, D. I., Wade, C. A., \& Persson, T. (2015). Strategies for teaching students to think critically: A meta-analysis. Review of Educational Research, 85 (2), 275-314.

Alexander, P. A., Dinsmore, D. L., Fox, E., Grossnickle, E. M., Loughlin, S. M., Maggioni, L., ... Winters, F. I. (2011). Higher order thinking and knowledge: Domain-general and domain-specific trends and future directions. In G. Schraw \& D. R. Robinson (Eds.), Current perspectives on cognition, learning, and instruction. Assessment of higher order thinking skills (pp. 47-88). Charlotte, NC, US: IAP Information Age Publishing.

Bandman, E. L. (1988). Critical thinking in nursing. Appleton \& Lange, New York, N.Y.

Bergman, L. R., \& Magnusson, D. (1997). A person-oriented approach in research on developmental psychopathology. Development and Psychopathology, 9 (2), 291-319. https://doi.org/10.1017/ S095457949700206X.

Budsankom, P., Sawangboon, T., Damrongpanit, S., \& Chuensirimongkol, J. (2015). Factors affecting Higher Order Thinking Skills of students: A meta-analytic Structural Equation Modeling study. Educational Research and Review, 10 (19), 2639-2652. https://doi.org/10.5897/ERR2015.

Clark, S. L. (2010). Mixture modeling with behavioral data. University of California, Los Angeles, CA.

Dewey, J. (1999). How we think. Science, 283 (5408), 1601o-1601. https://doi.org/10.1126/ science.283.5408.16010.

Facione, P. A. (1990). Critical thinking : A statement of expert consensus for purposes of educational assessment and instruction executive summary. The California Academic Press, 423 (c), 1-19. https://doi.org/10.1016/j.tsc.2009.07.002.

Jeon, S.-H. (2010). Study and research for applaying media education to improve advanced thinking skill in social study education. Unpublished Doctoral Disseration. University of Seoul, Seoul, South Korea.

Jin-sook, K. (2011). Development of Higher-order Thinking in moral education. Journal of Ethics and Phyiosophy Education, 16, 45-69.

Kemp, C. G. (1963). Improvement of critical thinking in relation to open-closed belief systems. Journal of Experimental Education, 31(3), 321-323. https://doi.org/10.1080/00220973.1963.11010784

Kim, M. (2007). Factor construct and other sychometric characteristics of KICE Critical Thinking Test as a complex Higher-Order Thinking test. Korea Journal of Educational Psychology, 21 (3), 513-537.

Kim, S., Ahn, J., \& Lee, J. (2014). A study on the development of caring scale items. Journal of Social Science, 25 (1), 81-104.

Kim, S., \& Hong, K. J. (2010). A study on the welfare attitude of Seoul citizens using the Latent Class Analysis. Korea Journal of Social Welfare, 37 (2), 95-121.

Lee, M.-S. (2016). Development of the Higher-Order Thinking skill scale for Korean University Students. Unpublished Doctoral Disseration, Gangneung-Wonju National University, South Korea.

Lewis, A., \& Smith, D. (1993). Defining Higher Order Thinking. Theory Into Practice, 32 (3), 131-137. https://doi.org/10.1080/00405849309543588.

Lipman, M. (1995). Moral education higher order thinking and philosophy for children. Early Child Development and Care, 107 (1), 61-70. https://doi.org/10.1080/0300443951070108.

Lipman, M. (2003). Thinking in education, Second edition. Cambridge University Press, Cambridge: U.K. https://doi.org/10.1017/CBO9780511840272.

Mokhtar, M. Z., Tarmizi, M. A. A., Tarmizi, R. A., \& Ayub, A. F. M. (2010, July). Problem-based learning in calculus course: perception, engagement and performance. In Proceedings of the 7th WSEAS international conference on engineering education. Stevens Point, Wisconsin, USA: World Scientific and Engineering Academy and Society (WSEAS) (pp. 21-5).

Newmann, F. M. (1991). Higher order thinking in the teaching of social studies: Connections between theory and practice. In J. F. Voss, D. N. Perkins, \& J. W. Segal (Eds.), Informal reasoning and education, 381-400. Lawrence Erlbaum Assoiation, Inc., Hillsdale, New Jersey.

Norris, P. (1985). Women's legislative participation in Western Europe. West European Politics, 8 (4), 90-101. https://doi.org/10.1080/01402388508424556.

Onyekuru, B. U. (2015). Field dependence vs. field independence cognitive style, gender, career choice and academic achievement of secondary school students in emohua local government area of rivers state. Journal of Education and Practice, 6 (10), 76-85. 
O’Sullivan, M., \& Guilford, J. (1975). Six factors of behavioral cognition: Understanding other people. Journal of Educational Measurement, 12 (4), 255-271. https://doi.org/10.1111/j.1745-3984.1975. tb01027.x.

Park, E.-H. (2011). Development and validity of the caring thinking scale for youth. Unpublished Doctoral Disseration. Myoungii University, Seoul, South Korea.

Raiyn, J., \& Tilchin, O. (2015). Higher-Order Thinking development through adaptive Problem-Based Learning. Journal of Education and Training Studies, 3 (4). https://doi.org/10.11114/jets.v3i4.769.

Samo, D. D., Darhim, D., \& Kartasasmita, B. (2017). Developing contextual Mathematical thinking learning model to enhance Higher-Order Thinking ability for middle school students. International Education Studies, 10 (12), 17. https://doi.org/10.5539/ies.v10n12p17.

Schumacker, R. E., \& Lomax, R. G. (2010). A beginner's guide to Structural Equation Modeling (3rd Edition), New York: Taylor \& Francis Group.

Seo, M. O. (2003). Study of the relationships that preservice teacher's gender and major on thinking styles and creative personality. Korea Journal of Education, 41 (4), 259-283.

Torrance, E. P. (1988). The nature of creativity as manifest in its testing. In R. J. Sternberg (Ed.), The nature of creativity: Contemporary psychological perspectives, 43, Cambridge University Press: New York, NY.

Vidergor, H. E., \& Krupnik-Gottlieb, M. (2015). High Order Thinking, Problem Based and Project Based Learning in Blended Learning Environments. In Applied Practice for Educators of Gifted and Able Learners (pp. 217-232), Rotterdam: SensePublishers.

Yang, J., Kim, C., \& Hwang, Y. (2007). A study of Korean consumer's choice behavior of brand using Latent Class Model -Competitive Structure Analysis of acid beverage market. The Journal of Productivity, 21 (4), 149-170. 
PROBLEMS

OF EDUCATION IN THE $21^{\text {st }}$ CENTURY Vol. 76 , No. 4, 2018

498

\section{Appendix}

Higher-Order Thinking Skill Scale for Korean University Students (HOTUS) by Lee (2016)

\begin{tabular}{|c|c|c|}
\hline No. & Item & Factor \\
\hline 1 & I review what I studied in class to solve a task. & Analysis \\
\hline 2 & $\begin{array}{l}\text { When I study, I try to interpret the meanings contained in learning materials such as } \\
\text { graphics and pictures. }\end{array}$ & Analysis \\
\hline 3 & I don't just memorize what I am going to learn, but I rather think about it carefully first. & Analysis \\
\hline 4 & When I get stuck while studying, I guess the topic in the context. & Analysis \\
\hline 5 & When I solve a task, I look for ways other than the way I have always used. & Creativity \\
\hline 6 & I make novel ideas from different sources which my teacher did not suggest. & Creativity \\
\hline 7 & I try to give more unique opinions than other friends. & Creativity \\
\hline 8 & When I solve a task, I use different methods from others. & Creativity \\
\hline 9 & I look for various grounds to solve a task. & Argumentation \\
\hline 10 & When I solve a task, I draw conclusions based on actual data. & Argumentation \\
\hline 11 & When I collect learning materials, I look for errors based on accurate evidence. & Argumentation \\
\hline 12 & When I solve a task, I tend to draw conclusions based on various data. & Argumentation \\
\hline 13 & I decide on an answer based on rational judgment and provide evidence. & Argumentation \\
\hline 14 & I present many opinions when I discuss with other friends. & Dialectic \\
\hline 15 & When I discuss, I put together different opinions and then present a new opinion. & Dialectic \\
\hline 16 & $\begin{array}{l}\text { I tend to induce my friends to change their viewpoints so that we can agree on one } \\
\text { opinion. }\end{array}$ & Dialectic \\
\hline 17 & I try to put different issues together and suggest ways to help solve the problems directly. & Dialectic \\
\hline 18 & I examine pros and cons of other people's opinions and accept them as one opinion. & Dialectic \\
\hline 19 & I actively gather and accept opinions of others. & Caring \\
\hline 20 & I make a decision after listening to others. & Caring \\
\hline 21 & I do not ignore other people's different opinions when I make a decision. & Caring \\
\hline 22 & $\begin{array}{l}\text { If my friend tells me that my way of solving a task is wrong, I willingly accept that opinion } \\
\text { and try to change the solution. }\end{array}$ & Caring \\
\hline 23 & I explain to others who have different opinions so that they don't feel offended. & Caring \\
\hline 24 & $\begin{array}{l}\text { When I work on a team assignment, I am always mindful of keeping the given rules so as } \\
\text { not to interfere with the team. }\end{array}$ & Caring \\
\hline 25 & When I disagree with other friends, I try to understand them. & Caring \\
\hline
\end{tabular}

